\title{
Postsynaptic Calcium/Calmodulin-Dependent Protein Kinase II Is Required to Limit Elaboration of Presynaptic and Postsynaptic Neuronal Arbors
}

\author{
Dong-Jing Zou and Hollis T. Cline \\ Cold Spring Harbor Laboratory, Cold Spring Harbor, New York 11724
}

Neuronal dendritic and axonal arbors grow to a characteristic size and then stabilize their structures. Activity-dependent stop-growing signals may limit neuronal process elaboration. We tested whether endogenous calcium/calmodulindependent protein kinase II (CaMKII) activity in postsynaptic optic tectal cells is required to restrict the elaboration of neuronal processes in the Xenopus tadpole retinotectal projection. Optic tectal cells were infected with vaccinia viruses that express CaMKII-specific inhibitory peptides. In vivo time-lapse imaging revealed that expression of CaMKII inhibitors blocked the growth restriction that normally occurs during maturation of tectal cell dendritic arbors. Postsynaptic CaMKII inhibition also increased the growth of presynaptic retinotectal axon arbors. The results indicate that endogenous postsynaptic CaMKII activity is required to limit the growth of presynaptic and postsynaptic arbor structures in vivo.

Key words: CaMKII; retinotectal; Xenopus; in vivo imaging; structural plasticity; vaccinia virus
During brain development, neurons elaborate complex dendritic and axonal arbors that reach a characteristic size (Peters and Jones, 1984). Limiting neuronal growth is important for the formation of functional neuronal circuits. Expansion of dendritic or axonal arbors beyond their normal territories would likely degrade information transfer between different brain regions and interfere with integrative functions (Mainen and Sejnowski, 1996). Mechanisms that limit the growth of dendritic and axonal arbors may include activity-dependent signals that stabilize neuronal structure. Calcium/calmodulin-dependent protein kinase II (CaMKII) has been proposed to translate synaptically driven $\mathrm{Ca}^{2+}$ elevations into longer lasting changes in neuronal structures (Lisman, 1994). Here, we tested whether postsynaptic CaMKII is required to limit the elaboration of neuronal arbors during maturation of the nervous system.

In the Xenopus retinotectal projection, developing optic tectal neurons go through a period of rapid dendritic arbor elaboration, after which arbor growth rate slows (Wu et al., 1999). The transition to the slower growth rate correlates with the onset of CaMKII expression in tectal neurons ( $\mathrm{Wu}$ and Cline, 1998). Immature tectal cells have simple dendritic arbors, low levels of CaMKII immunoreactivity, and a rapid dendritic growth rate. Mature tectal cells have complex dendritic arbors, high levels of CaMKII immunoreactivity, and a slower dendritic arbor growth rate (Wu and Cline, 1998). Presynaptic retinal axons undergo a similar pattern of arbor elaboration (O'Rourke and Fraser, 1990; Zou and Cline, 1996a). Premature viral expression of the cata-

Received June 9, 1999; revised Aug. 3, 1999; accepted Aug. 4, 1999.

This work was supported by the National Institutes of Health. We thank K. P. Giese for helpful discussions, H. Fujisawa for the generous gift of AIP, G. Enikolopov for help designing inhibitory peptide constructs, H. Zhou and J.C.P. Yin for their advice during subcloning, B. Burbach, K. Bronson, I. Miloslavskaya, and N. Dawkins for excellent technical support, D. Rosa and R. Bari for help with data analysis, N. Peunova and S. John for various plasmids, and members of the laboratory for comments on this manuscript.

Correspondence should be addressed to Hollis Cline, Cold Spring Harbor Laboratory, Cold Spring Harbor, NY 11724.

Copyright () 1999 Society for Neuroscience $0270-6474 / 99 / 198909-10 \$ 05.00 / 0$ lytic domain of CaMKII in the tectal cells is sufficient to stabilize tectal cell dendritic arbors and retinal axons (Zou and Cline, 1996a; Wu and Cline, 1998). Although the induction of a CaMKII inhibitor in Drosophila motoneurons and muscles results in larger and more complex motor nerve terminals (Wang et al., 1994), no studies have yet demonstrated whether endogenous postsynaptic CaMKII activity is required to restrict neuronal process elaboration. To test whether endogenous CaMKII activity is necessary to stabilize the structure of tectal cells and presynaptic retinal axon arbors, CaMKII-specific inhibitory peptides were virally expressed in tectal cells. The development of both presynaptic and postsynaptic structures in the Xenopus tadpole retinotectal projection was then observed in vivo with timelapse confocal imaging. We found that CaMKII inhibitor expression in tectal cells prevented the restriction of arbor growth normally seen in both tectal neurons and presynaptic retinal axons. These results indicate that endogenous CaMKII activity in tectal neurons is required to control the elaboration of both presynaptic and postsynaptic neuronal processes.

\section{MATERIALS AND METHODS}

Kinase assays. The brains of stage 48 albino Xenopus tadpoles (Nieuwkoop and Faber, 1956) anesthetized in 0.02\% 3-aminobenzoic acid (MS222) were rapidly dissected and homogenized. The protein content [determined by using a kit from Bio-Rad (Hercules, CA)] in the homogenates were normalized to $0.4 \mathrm{mg} / \mathrm{ml}$. CaMKII-specific activity was determined as before by using Syntide- 2 as substrate and $\mathrm{Ca}^{2+} /$ calmodulin as activators (Zou and Cline, 1996a). The protein kinase C (PKC)specific activity was measured by using myelin basic protein $(4-14)$ as substrate and phorbol 12-myristate 13-acetate and phosphatidyl serine as activators (protein kinase $\mathrm{C}$ assay system; Life Technologies, Gaithersburg, MD). The reaction was terminated after 4 min incubation at $25^{\circ} \mathrm{C}$. The effects of inhibitory peptides on kinase activity were normalized to the total activity from the same homogenates without inhibitors.

In kinase assays for screening the most effective recombinant virus on inhibiting CaMKII activity, RK13 cells were infected with purified virus $\left(1 \times 10^{6}\right.$ pfu to $4 \times 10^{5}$ cells) for $24-48 \mathrm{hr}$, harvested, and homogenized. The reaction was terminated after $3 \mathrm{~min}$ incubation at $25^{\circ} \mathrm{C}$.

Virus construction. Synthesized DNA fragments encoding inhibitory peptides were inserted into the vaccinia recombinant vector pSC65. The 
inhibitory peptide constructs encoded a stabilizing domain derived from the rat protein kinase A regulatory domain (PKA RI ${ }_{(21-108)}$ ) (Reilein et al., 1998), inhibitor, and myc epitope tag (EQKLISEEDL) (Evan et al., $1985)$, followed by a stop codon and rabbit $\beta$-globulin splicing isoform with poly(A) signal. In the recombinant vaccinia virus, the peptide was driven by a strong synthetic early-late vaccinia promoter. The reporter $\beta$-galactosidase ( $\beta$-gal) gene was driven by the $\mathrm{p} 7.5$ vaccinia promoter. In the inhibitor domain of three plasmids relevant to this study, DJ19 encoded autocamtide-2-related inhibitory peptide (AIP) (KKALRRQEAVDAL) (Ishida et al., 1995), DJ15 encoded [Ala ${ }^{286}$ ] CaMKII ${ }_{(281-}$ 302) (Ala ${ }^{286}$ a) (MHRQEAVDCLKKFNARRKLKGA) (Smith et al., 1992), and DJ18 encoded the inactive mutant of Ala ${ }^{286}$ a (Ala ${ }^{286}$ ) (MDGEETVDCLKKFNARRKLKGA) (Waldmann et al., 1990).

Homologous recombination of the pSC65 plasmids and the wild-type vaccinia virus was performed in RK13 cells (Mackett et al., 1985). Recombinant virus was selected by three rounds of blue plaque assays in thymidine kinase-negative cells (TK-143). Virus was enriched in RK13 cells and purified through a sucrose gradient with titers $\sim 10^{9} \mathrm{pfu} / \mathrm{ml}$.

To examine the expression pattern of the inhibitory peptides, stage $47 / 48$ tadpoles were infected with the recombinant viruses. The animals were fixed with $4 \%$ paraformaldehyde in $0.1 \mathrm{~m}$ phosphate buffer, $\mathrm{pH} 7.4$, overnight at $4^{\circ} \mathrm{C}$. Sections were immunostained with myc tag-specific antibody (9E10, 1:100 dilution; Calbiochem, La Jolla, CA) and imaged with a confocal microscope. All chemicals were purchased from Sigma (St. Louis, MO) unless otherwise noted.

Imaging and morphological data analysis. Tectal cells and retinal axons were labeled in separate groups of animals using DiI labeling. To label single tectal neurons, $0.01 \%$ DiI in absolute ethanol was iontophoresed into the dorsomedial optic tectum of stage 47/48 tadpoles anesthetized in $0.02 \%$ MS-222. After 1-2 hr, animals were screened to select those with single brightly labeled neurons. To label single retinotectal axons, $0.5 \%$ DiI was iontophoresed into the right midtemporal retina of stage 46 tadpoles. The next day, animals were screened to select those with individual brightly labeled retinal axons.

Images of entire individual DiI-labeled tectal neurons or retinotectal axon arbors were acquired with a confocal microscope (Odyssey; Noran Instruments, Middleton, WI) by taking serial $2 \mu \mathrm{m}$ optical sections. Between imaging sessions, animals were maintained in an incubator at $25^{\circ} \mathrm{C}$ under red light illumination with a $12 \mathrm{hr}$ dark/light cycle. After the last image was collected, animals were fixed, and the extent of virus infection was checked by examining the expression of $\beta$-gal with the $\mathrm{X}$-gal histochemistry in the whole-mount animals (Zou and Cline, 1996a).

Tectal cells and retinal axons were reconstructed by tracing the portion of the arbor from each optical section onto an acetate sheet until the entire arbor was drawn. Local axon branches were defined as the collateral branches from the efferent axons separated by at least $30 \mu \mathrm{m}$ from the dendritic arbors. Local axons of tectal neurons could be distinguished from dendrites because they were thinner caliber than dendrites, they were located in a deeper optical sections within the $z$-axis of the neurons, and they were sparsely branched near the cell body. The length of total arbor branches in the reconstructed tectal cells and retinal axons was measured with NIH Image 1.61. Growth rate was determined as the branch length difference between two observations. Data were presented as mean \pm SEM. Statistical significance was determined by using independent two-populations $t$ test. A total of 172 tectal cells from 142 animals and 94 retinal axons from 89 animals were successfully reconstructed for the quantitative analysis.

\section{RESULTS}

\section{Viral expression of CaMKII inhibitors}

Binding of the autoinhibitory domain to the catalytic domain inactivates CaMKII (Miller and Kennedy, 1986; Schworer et al., 1988). Based on the amino acid sequence of the autoinhibitory domain, several inhibitory peptides have been designed (Colbran et al., 1988; Kelly et al., 1988; Payne et al., 1988; Malinow et al., 1989). A recently developed inhibitor, AIP, is a potent and highly specific CaMKII inhibitor with little inhibitory activity on other $\mathrm{Ca}^{2+}$-dependent kinases, including PKC and $\mathrm{Ca}^{2+} /$ calmodulindependent protein kinase IV (Ishida et al., 1995). To test whether AIP specifically inhibits CaMKII but not PKC in frog brains, we performed kinase assays in brain homogenates from Xenopus
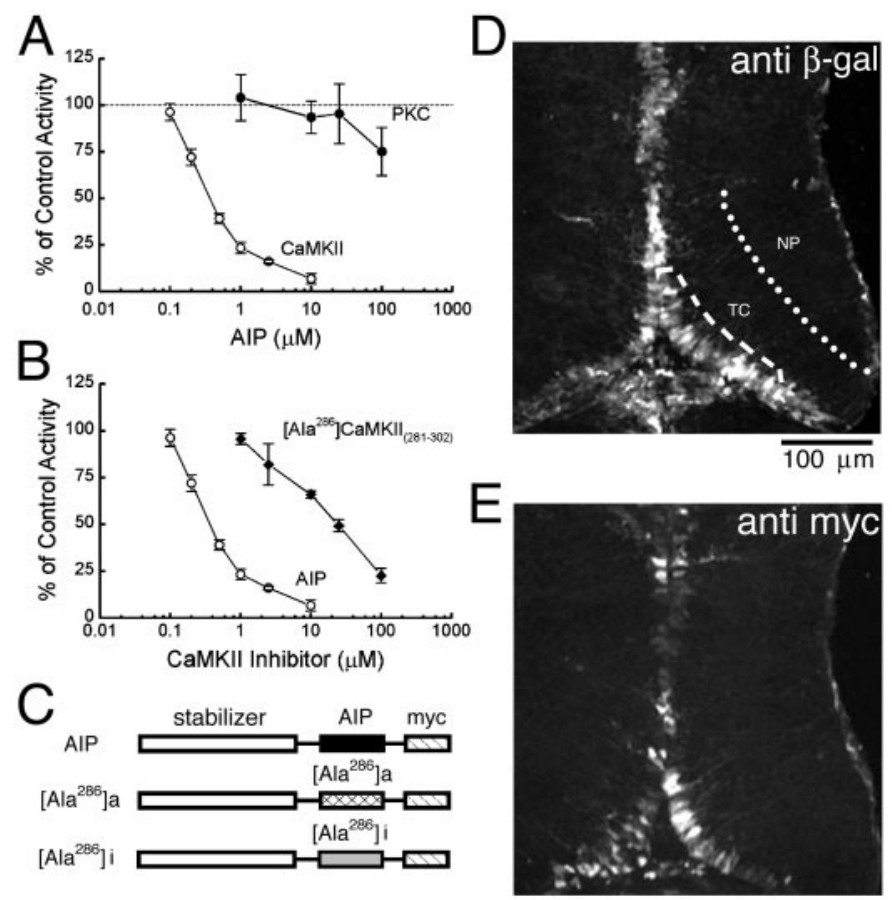

Figure 1. Expression of CaMKII-specific inhibitors. $A$, Parallel kinase assays show that AIP specifically inhibits CaMKII but not PKC activity. $B$, AIP is a more potent CaMKII inhibitor than $\mathrm{Ala}^{286} \mathrm{a}$. $C$, CaMKII inhibitory peptides expressed by recombinant vaccinia viruses. $D$, Immunostaining of the reporter $\beta$-galactosidase in a single optical section through the tectum $2 \mathrm{~d}$ after virus infection. Single tectal cells were labeled in the region marked by the dashed line. E, Expression of inhibitory peptide AIP detected by using anti-myc in a neighboring section. $N P$, Neuropil region of tectum; $T C$, tectal cell body layer.

tadpoles. AIP strongly inhibited CaMKII activity with an $\mathrm{IC}_{50}$ estimated as $0.4 \mu \mathrm{M}$ (Fig. $1 A$ ). At $10 \mu \mathrm{M}$, AIP inhibited CaMKII activity almost completely ( $7 \pm 3 \%$ of the control) but did not block PKC activity (94 $\pm 9 \%$ of the control) in the same homogenates $(n=4)$. Another CaMKII inhibitor, Ala ${ }^{286} \mathrm{a}$, inhibited CaMKII activity with a higher $\mathrm{IC}_{50}$ of $25 \mu \mathrm{M}(n=4)$ (Fig. $\left.1 B\right)$. These results indicate that AIP is a specific and potent inhibitor for CaMKII activity in frog neural tissue.

To express CaMKII inhibitors in tectal neurons, we constructed a series of recombinant vaccinia viruses. Kinase assays in homogenates of RK13 cells infected with these viruses showed that the most effective construct at inhibiting CaMKII activity encoded the inhibitor AIP, a stabilizing domain derived from rat PKA regulatory domain (Reilein et al., 1998), and a myc epitope tag. This is referred to as the AIP virus. In RK13 cell kinase assays, up to $70 \%$ of CaMKII activity was inhibited by the AIP virus. A similar virus in which AIP was replaced by $\mathrm{Ala}^{286} \mathrm{a}$ (Ala ${ }^{286}$ a virus) decreased CaMKII activity to $\sim 40 \%$ of the control value. A virus that encoded an inactive form of $\mathrm{Ala}^{286} \mathrm{a}$ (Waldmann et al., 1990) did not block CaMKII activity and was used as a control virus (Ala ${ }^{286}$ i virus) (Fig. $1 C$ ). In samples from either RK13 cells or frog brains infected with virus, a band of $\sim 13$ $\mathrm{kDa}$ was detected in Western blots probed for the myc tag, consistent with the predicted size of the inhibitors.

To examine the distribution pattern of virally expressed CaMKII inhibitors in the tectum, stage 46/47 tadpoles were infected with the AIP virus. In our recombinant vaccinia viruses, the gene of interest was under the control of a stronger vaccinia promoter, and the reporter $\beta$-gal was driven by a weaker vaccinia 


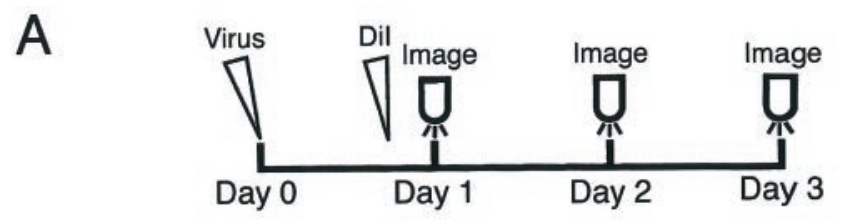

B Control Tectal Cells

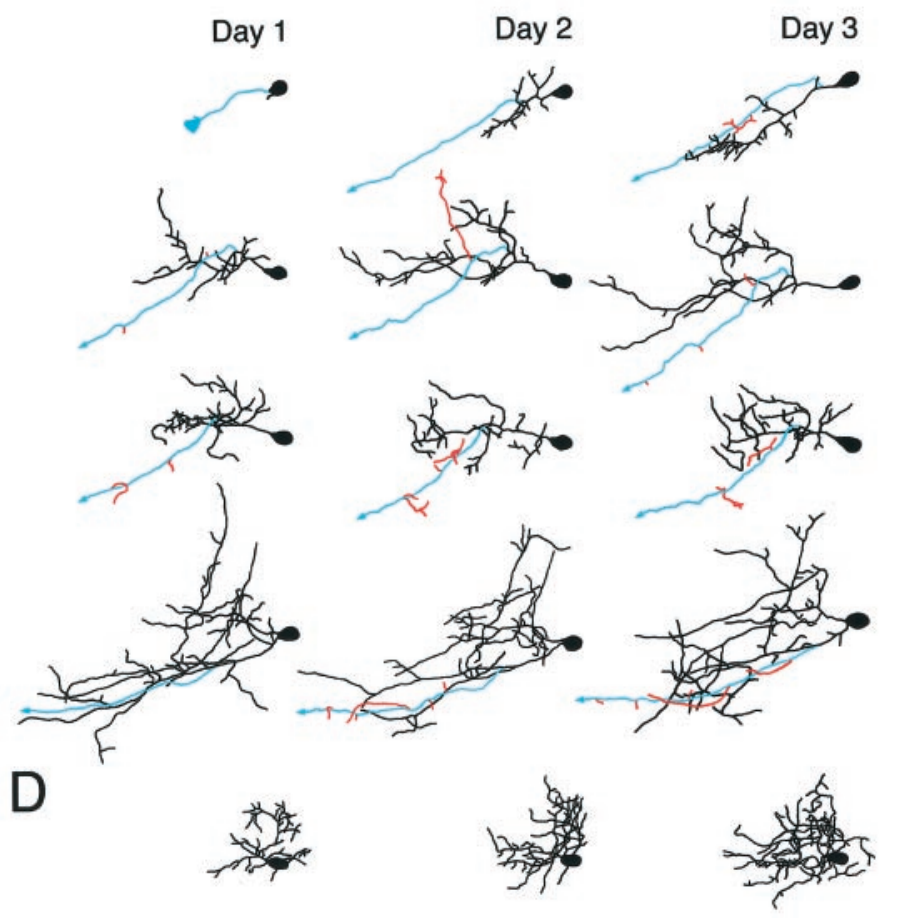

\section{AIP Tectal Cells}

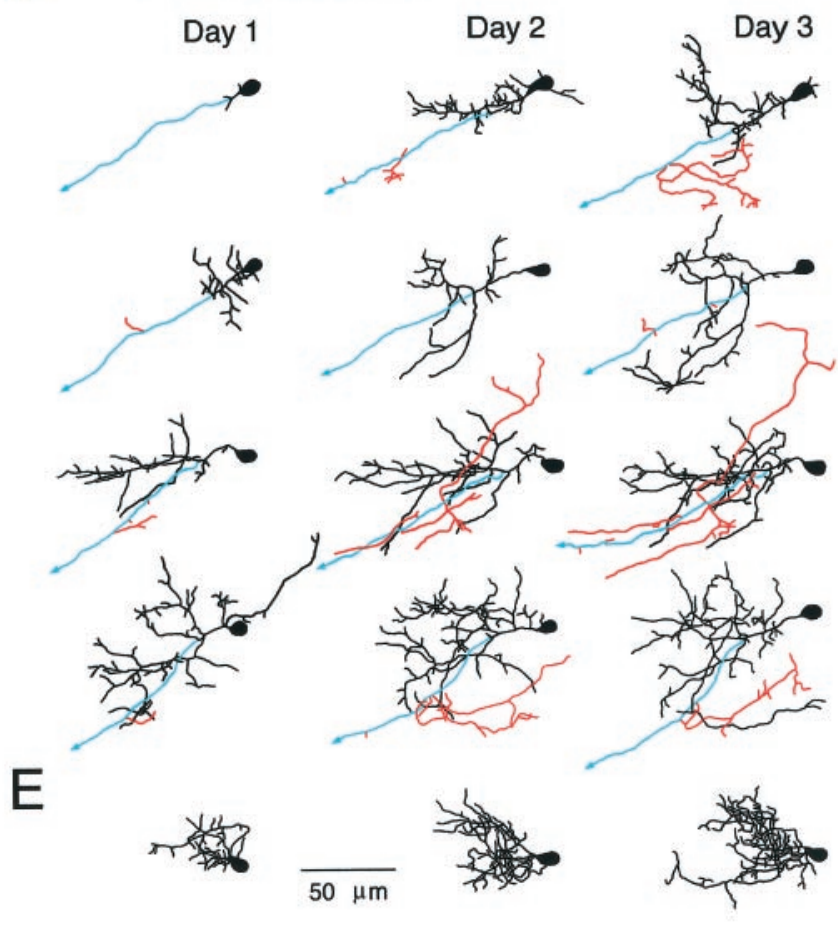

Figure 2. AIP expression increases the elaboration of mature tectal projection neurons but not interneurons. Protocol for viral infection, DiI labeling, and in vivo imaging of tectal cells $(A)$. On day 0 , virus was injected into the tectal ventricles. On day 1 , individual tectal neurons were labeled with DiI and imaged with a confocal microscope. On days 2 and 3, the same tectal neurons were imaged again. Examples of reconstructed control projection cells $(B)$, AIP projection cells $(C)$, control interneurons $(D)$, and AIP interneurons $(E)$ imaged daily over 3 d. Day 1 , Left columns; day 2, middle columns; day 3 , right columns. Cells of increasing arbor complexity are displayed from top to bottom, and the growth rates of these cells were close to the means of their treatment groups. Black, Dendrites; blue, axons; red, local axon branches. Arrows mark axons that exit the tectum.

promoter. Foreign gene expression could first be detected $24 \mathrm{hr}$ after virus injection. Expression levels increased over the next 24 hr period so that extensive expression of both $\beta$-gal (Fig. $1 D$ ) and myc-tagged AIP (Fig. 1E) were observed. The examples shown in Figure $1, D$ and $E$, represented the median level of viral expression. It is important to note that the images of $\beta$-gal and myc immunoreactivity shown in the figure under-represent the fraction of infected cells, because they were from a single confocal optical plane in the section. The foreign gene products were located in the cell bodies, as well as in the neuronal processes in the tectum. The immunoreactivity for the reporter $\beta$-gal appeared to be more intense than that for the myc-tagged AIP, likely because of the greater stability of $\beta$-gal and the quality of the antibodies. Together, these results suggest that recombinant vaccinia viruses express inhibitory peptides in Xenopus tectal neurons, which are capable of decreasing endogenous CaMKII activity.

\section{Endogenous CaMKII activity and tectal cell growth}

To test whether CaMKII activity is required to restrict the growth of tectal neurons, we used in vivo imaging combined with viral expression of CaMKII inhibitory peptides (Fig. 2A). CaMKII expression levels are developmentally regulated in tec- tal neurons, such that neurons with complex dendritic arbors, measuring $>300 \mu \mathrm{m}$ in total dendritic branch length (TDBL) express CaMKII, whereas neurons with simpler dendritic arbors, measuring $<300 \mu \mathrm{m}$ TDBL do not (Wu and Cline, 1998). We therefore took advantage of the rostrocaudal gradient of neuronal development in the optic tectum by imaging neurons at different positions along the rostrocaudal developmental axis to determine whether expression of CaMKII inhibitor selectively modified morphological development of mature CaMKII-expressing neurons.

Uninfected control projection neurons imaged from the immature caudal tectum had simple dendritic arbors and rapidly became more elaborate over the $3 \mathrm{~d}$ imaging session. Neurons from more mature rostral tectum had more dendrites, and their dendritic arbors were more stable than those of simple neurons from caudal tectum (Fig. 2B). Tectal neurons in AIP virus-infected animals (AIP neurons) imaged from caudal tectum did not appear different from control neurons. In contrast, AIP neurons imaged from rostral tectum developed more elaborate arbors than controls. Furthermore, it appeared that both dendritic arbors and local axonal arbors grew more in AIP neurons (Fig. 2C).

In contrast to projection neurons, interneurons from both the 
Figure 3. AIP expression increases the elaboration of tectal projection neurons but not interneurons. Growth rate of all neuronal processes over $2 \mathrm{~d}$ in projection neurons $(A)$ and interneurons $(B)$. Branch tip number of all neuronal processes in projection neurons $(C)$ and interneurons $(D)$. Projection neurons: control cells, $n=38$; Ala ${ }^{286}$ i cells, $n=$ 44; AIP cells, $n=42$. Interneurons: control cells, $n=13$; Ala ${ }^{286}$ i cells, $n=19$; AIP cells, $n=16$.
A

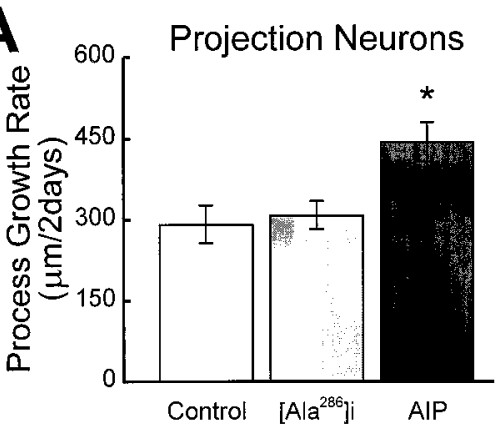

C

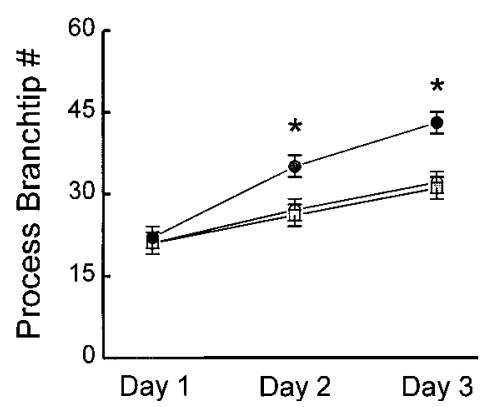

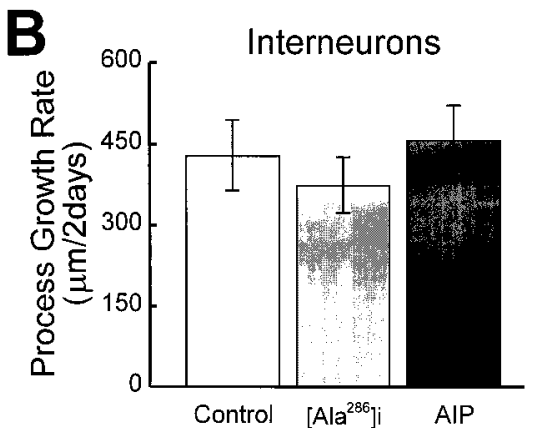

D

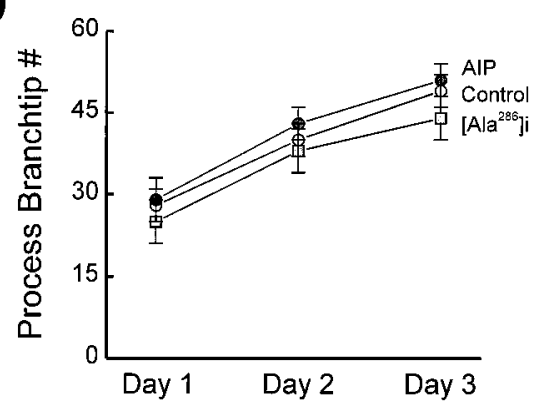

uninfected control (Fig. 2D) and the AIP virus-infected animals (Fig. 2E) had a comparable arbor complexity after $3 \mathrm{~d}$ of imaging. This is consistent with observations that local GABAergic interneurons do not express CaMKII (Benson et al., 1991; Liu and Jones, 1996; Sik et al., 1998) and would therefore be unaffected by
AIP expression. Dendritic growth in interneurons is likely regulated by mechanisms not involving CaMKII activity.

To analyze the effects of AIP expression on tectal cell growth, we first examined the combined data from all neuronal processes, including both dendrites (Fig. 2, black) and local axon branches
A

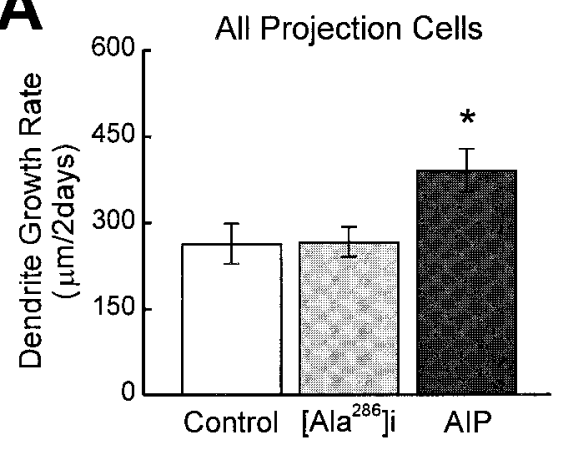

D

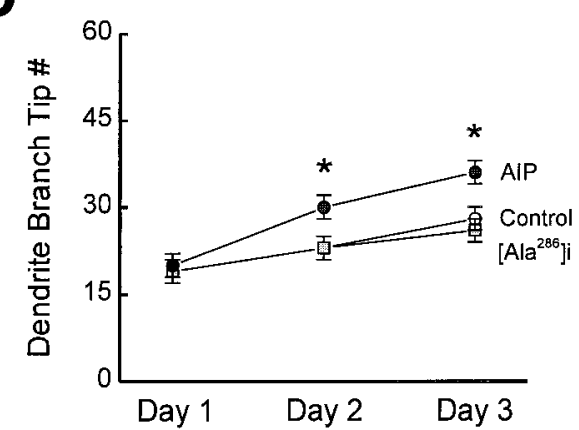

B

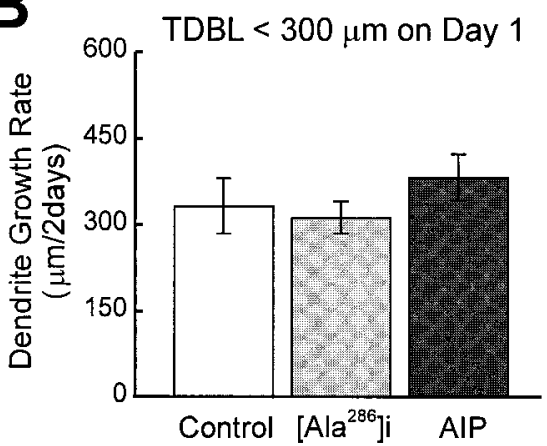

E

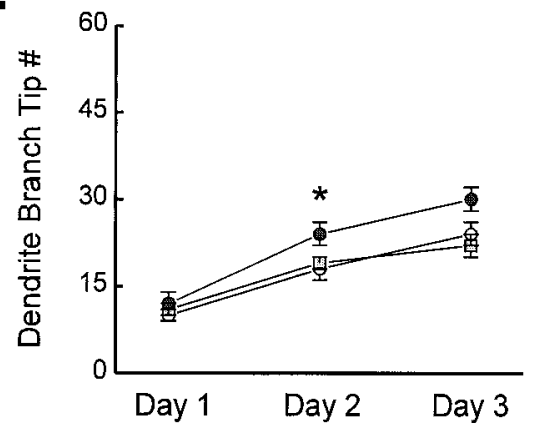

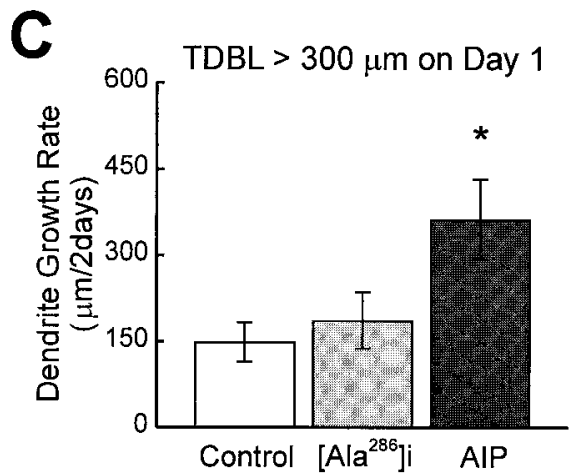

F

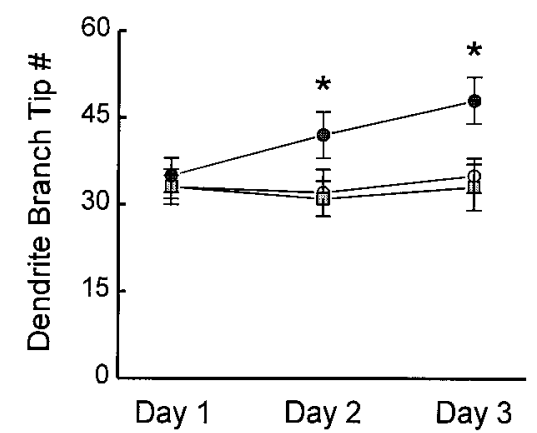

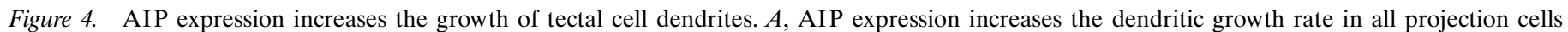

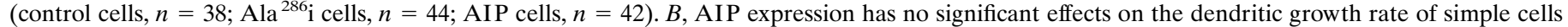

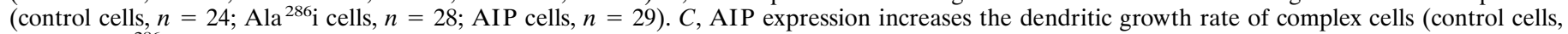

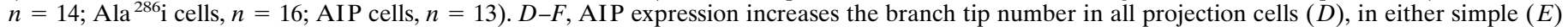
or complex $(F)$ cells. 

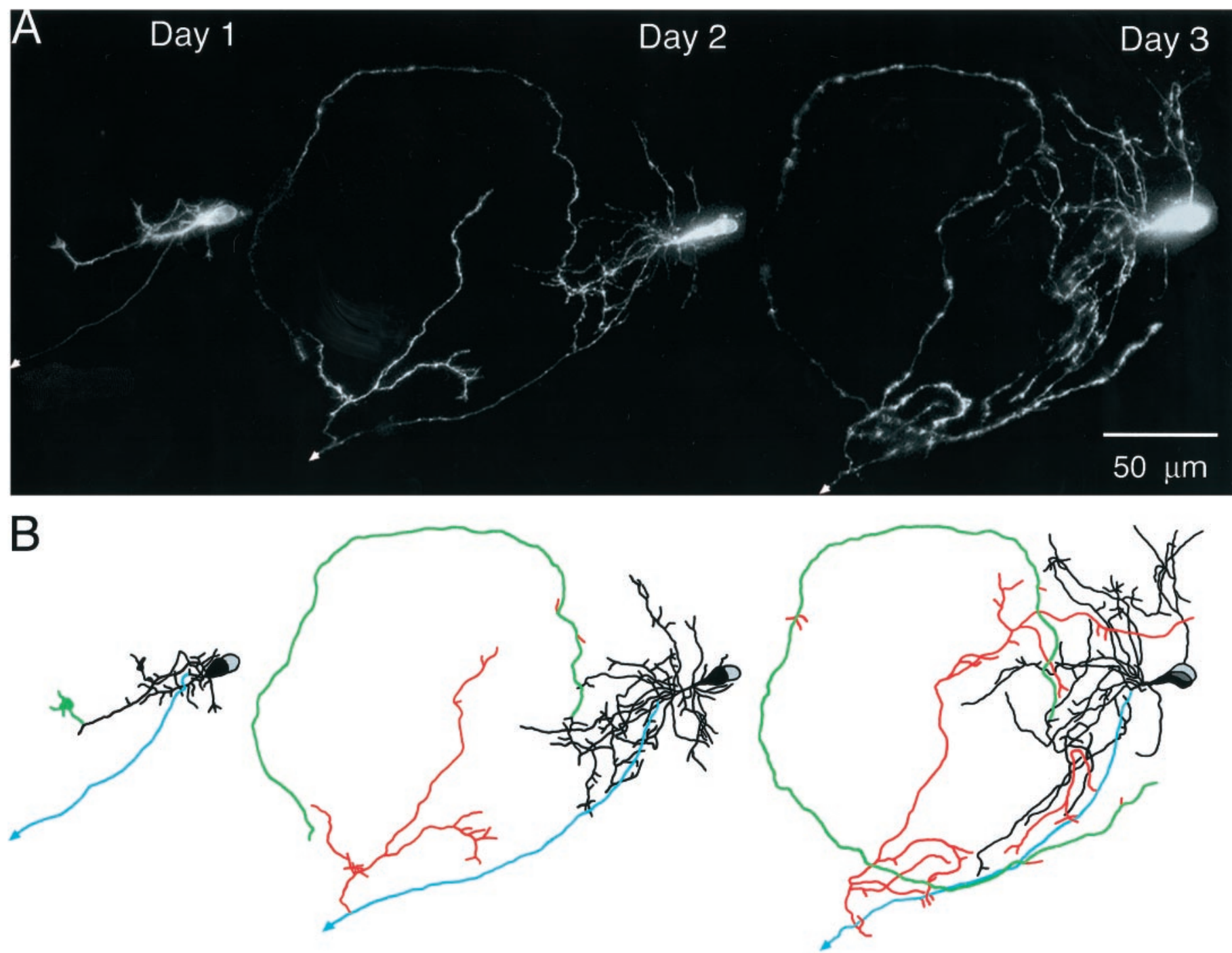

Figure 5. Elaboration of local axon arbors in tectal cells from tadpoles expressing AIP. Daily images $(A)$ and drawings $(B)$ of two cells with an unusual extent of axon arbor elaboration observed over 3 d. Black, Dendrites; blue, green, axons; red, local axon branches. Arrows mark axons that exit the tectum.

(Fig. 2, red). Then, we examined the data separately to test whether AIP expression changed the growth of different neuronal compartments in tectal cells. On the first day of imaging, all groups of tectal neurons from virus-infected and uninfected animals had similar initial values of either total branch length or branch tip number $(p>0.45)$.

\section{Total processes}

Uninfected control projection neurons $(n=38)$ had an average growth rate of $292 \pm 35 \mu \mathrm{m} / 2 \mathrm{~d}$. The total process length increased from $274 \pm 38 \mu \mathrm{m}$ on day 1 to $566 \pm 38 \mu \mathrm{m}$ on day 3 . The growth rate of AIP projection cells was significantly greater than controls $(444 \pm 36 \mu \mathrm{m} / 2 \mathrm{~d} ; n=42 ; p<0.005)$ (Fig. $3 A)$. The total process length increased from $246 \pm 30$ to $690 \pm 43 \mu \mathrm{m}$, significantly larger than control cells $(p<0.05)$. There was a corresponding increase in branch tip number of neuronal processes in AIP neurons from $22 \pm 2$ on day 1 to $43 \pm 2$ on day 3 , significantly more than the control neurons $(p<0.001)$ (Fig. $3 C)$.

Compared with projection neurons, interneurons from uninfected control animals had a higher growth rate of total branch length and a greater net addition of branch tips over $3 \mathrm{~d}$. AIP expression did not change interneuron growth rate $(457 \pm 64$ $\mu \mathrm{m} / 2 \mathrm{~d}$ for 16 AIP interneurons vs $429 \pm 65 \mu \mathrm{m} / 2 \mathrm{~d}$ for 13 control interneurons) (Fig. $3 B$ ). Furthermore, the branch tip numbers were not different between AIP interneurons and control interneurons (Fig. 3D). These results indicate that AIP expression selectively promotes the elaboration of neuronal processes in projection neurons.

The elaboration of tectal neurons from the inactive Ala ${ }^{286} \mathbf{i}$ control virus-infected animals was comparable with the growth of uninfected control neurons. Comparing Ala ${ }^{286} \mathbf{i}$ neurons with control neurons, the total branch length, the growth rate, and the branch tip number had similar values $(p>0.3)$. These results confirmed that recombinant vaccinia virus did not affect the development of tectal neurons when not encoding active inhibitor.

\section{Dendrites}

Dendrites of all AIP neurons had a growth rate $(377 \pm 35 \mu \mathrm{m} / 2$ d) significantly greater than controls $(264 \pm 35 \mu \mathrm{m} / 2 \mathrm{~d} ; p<0.05)$ (Fig. $4 A$ ). The total dendritic length for AIP neurons increased from $228 \pm 29 \mu \mathrm{m}$ on day 1 to $605 \pm 43 \mu \mathrm{m}$ on day 3 , whereas for 

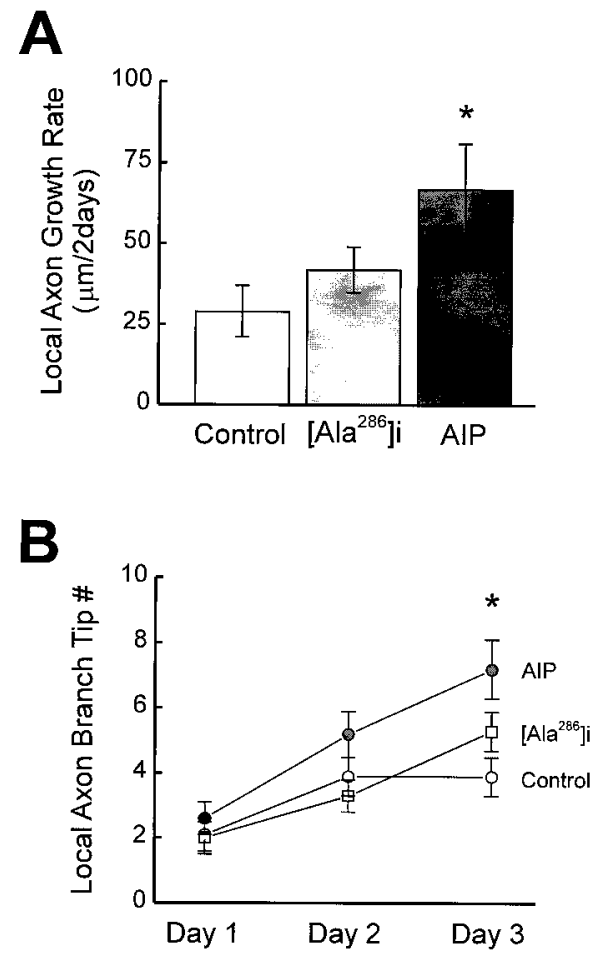

Figure 6. AIP expression increases the growth rate of branch length $(A)$ and branch tip number $(B)$ of local axons in tectal cells.

control neurons, it increased from $261 \pm 37$ to $525 \pm 38 \mu \mathrm{m}$. To test whether AIP expression selectively affected dendritic growth in simple CaMKII-deficient (TDBL $<300 \mu \mathrm{m}$ ) or complex CaMKII-expressing (TDBL $>300 \mu \mathrm{m}$ ) neurons, the growth of these neurons was analyzed separately. AIP expression did not significantly change the growth rate of simple neurons (Fig. 4B), consistent with the observation that these neurons do not yet express significant levels of CaMKII. In contrast, the growth rate of complex AIP neurons (363 $\pm 70 \mu \mathrm{m} / 2 \mathrm{~d} ; n=13)$ was significantly greater than complex control neurons $(149 \pm 34 \mu \mathrm{m} / 2 \mathrm{~d}$; $n=14 ; p<0.01$ ) (Fig. $4 C$ ). Furthermore, the growth rate of complex AIP neurons was comparable with the growth rate of control simple neurons, consistent with the idea that CaMKII activity is required to restrict dendritic arbor growth rate. Complex AIP neurons increased TDBL from $444 \pm 47 \mu \mathrm{m}$ on day 1 to $807 \pm 84 \mu \mathrm{m}$ on day 3 , whereas control neurons increased TDBL from $492 \pm 57$ to $641 \pm 51 \mu \mathrm{m}$ over the same period.

Over $3 \mathrm{~d}$, the branch tip number in all AIP projection neurons increased significantly more than controls $(p<0.05)$ (Fig. 4D). When simple and complex cells were analyzed separately, AIP expression significantly increased branch tip numbers in complex neurons compared with controls $(p<0.05)$ (Fig. $4 F)$.

\section{Local axon branches}

Based on drawings and images of control and AIP neurons (Figs. 2, 5), AIP expression appeared to promote the elaboration of local axon arbors. Figure 5 shows images and drawings of a pair of AIP neurons to illustrate the elaboration of local axon collaterals. These two cells were not included in the quantitative analysis because they could not be separated and analyzed as single neurons. An unusually large local axon arbor (red) emerged from an efferent axon (blue) on day 2. This axon arbor continued to elaborate on day 3. These local axon branches did not appear to exit the tectum. In contrast, the primary axon ( green), possibly from the second tectal cell, only had a few short local axon branches. AIP expression could have different effects on local axons in neighboring tectal neurons.

AIP neurons also had a significantly greater local axonal growth rate $(67 \pm 14 \mu \mathrm{m} / 2 \mathrm{~d})$ than control neurons $(29 \pm 8 \mu \mathrm{m} / 2$ d; $p<0.05$ ) (Fig. 6A). Local axon branch length in AIP neurons increased from $17 \pm 4 \mu \mathrm{m}$ on day 1 to $84 \pm 13 \mu \mathrm{m}$ on day 3 , significantly more than the controls (day $1,13 \pm 3 \mu \mathrm{m}$; day 3, $41 \pm$ $8 \mu \mathrm{m} ; p<0.01)$. Local axon branch tip number also increased significantly more than controls on day $3(p<0.01)$ (Fig. $6 B)$.

The growth of tectal cell local axons could be regulated in a cell-autonomous manner by CaMKII activity or through cellcell interactions with their postsynaptic targets, other tectal neurons. To distinguish these possibilities, we examined whether the elaboration of local axon branches correlated with the growth of dendritic arbors. No obvious correlation was found in the growth rate between the local axons and the dendritic arbors in either control or AIP neurons. Similarly, the total branch length or the branch tip number was not correlated between the local axon arbor and the dendritic arbor in both control and AIP neurons. Unlike dendritic arbor elaboration, local axon arbor growth did not differ between simple and complex AIP neurons. These analyses suggest that local axon arbor elaboration and dendritic growth in tectal cells are regulated differently by CaMKII activity.

\section{Postsynaptic endogenous CaMKII activity and presynaptic retinal axon growth}

In a separate set of experiments, we further tested whether decreasing endogenous CaMKII activity in the postsynaptic tectal cells regulates the elaboration of presynaptic retinal ganglion cell (RGC) axon arbors (Fig. 7A). Similar to tectal cells, normal retinal axon arbors (control axons) became more elaborate over $3 \mathrm{~d}$ as a result of dynamic branch additions or retractions, as well as branch extensions or shortenings (Fig. 7B). Retinal axons from AIP virus-infected animals (AIP axons) appeared to grow more over 2 d (Fig. $7 C$ ).

AIP axons had a growth rate $(207 \pm 28 \mu \mathrm{m} / 2 \mathrm{~d} ; n=22)$ significantly greater than control axons $(100 \pm 21 \mu \mathrm{m} / 2 \mathrm{~d} ; n=23$; $p<0.005$ ) (Fig. 8A). Total RGC axon branch length increased significantly more in AIP axons (day 1, $524 \pm 32 \mu \mathrm{m}$; day 3, $731 \pm$ $33 \mu \mathrm{m}$ ) compared with controls (day 1, $522 \pm 35 \mu \mathrm{m}$; day 3: $622 \pm$ $39 \mu \mathrm{m} ; p<0.05)$. RGC axons from the animals expressing the less potent $\mathrm{CaMKII}$ inhibitor Ala ${ }^{286}$ a (Ala ${ }^{286}$ a axons) increased growth rate to a value intermediate between controls and AIP axons $(164 \pm 28 \mu \mathrm{m} / 2 \mathrm{~d} ; n=24 ; p=0.073)$. Axons from animals infected with the inactive Ala ${ }^{286} i$ virus (Ala ${ }^{286} i$ axons) were comparable with the control axons. Before virus infection, all groups of axons from experimental and control animals were comparable $(p>0.45)$.

Unexpectedly, the branch tip number in AIP axons was not significantly more than in controls (Fig. 8B), although AIP expression did increase the length of individual branch tips on day $2(13.9 \pm 0.5 \mu \mathrm{m}$ in AIP axons; $n=741$; compare with $12.8 \pm 0.4$ $\mu \mathrm{m}$ in controls; $n=742 ; p=0.056)$. These results suggest that postsynaptic AIP expression promoted retinal axon growth by increasing the extension of individual axon branch segments but not by adding new branches. 


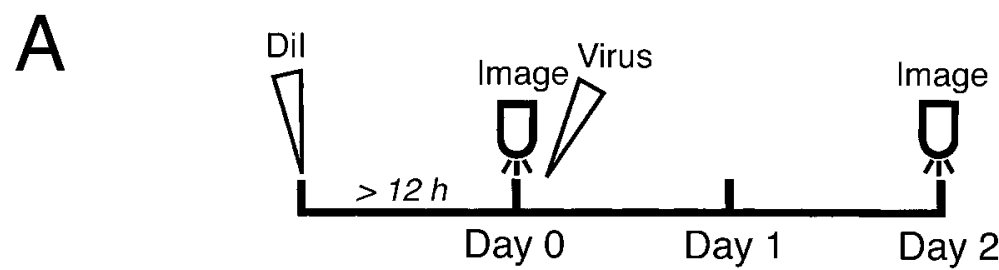

\section{B Control RGC Axons C AIP RGC Axons}
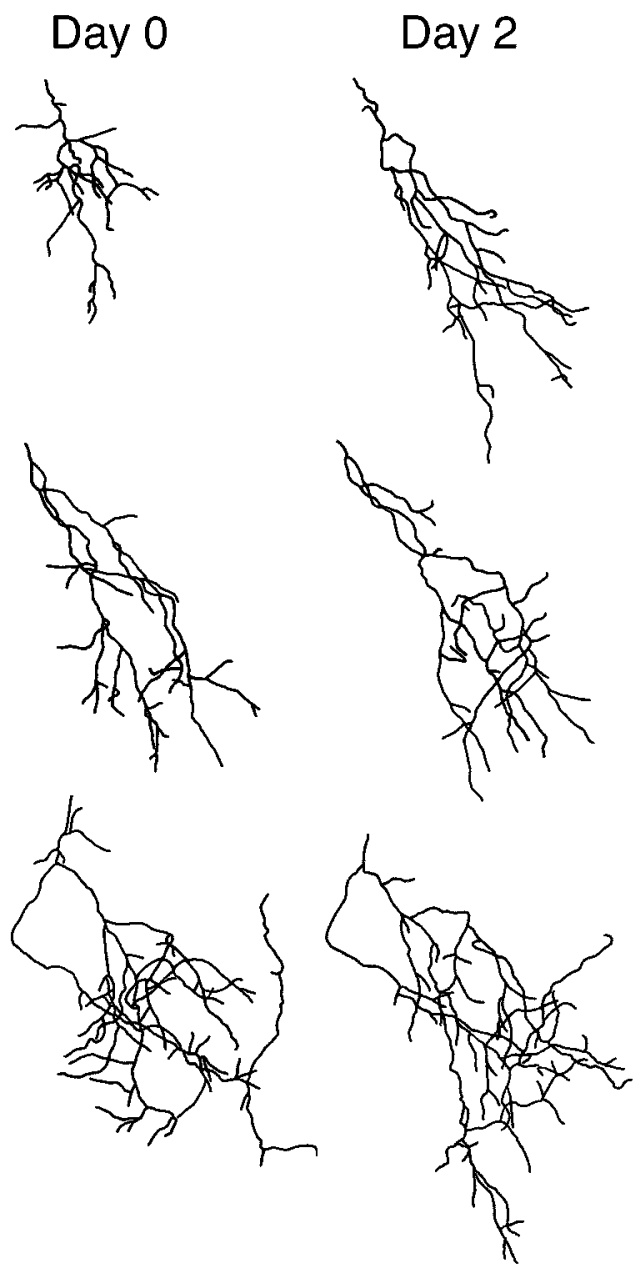

Day 2
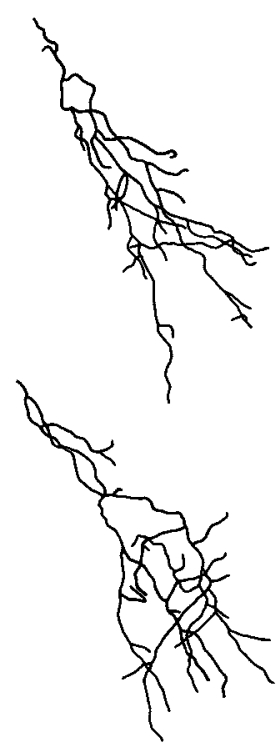
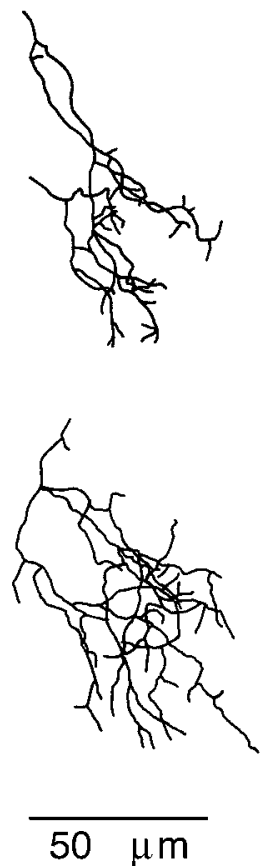

Day 2
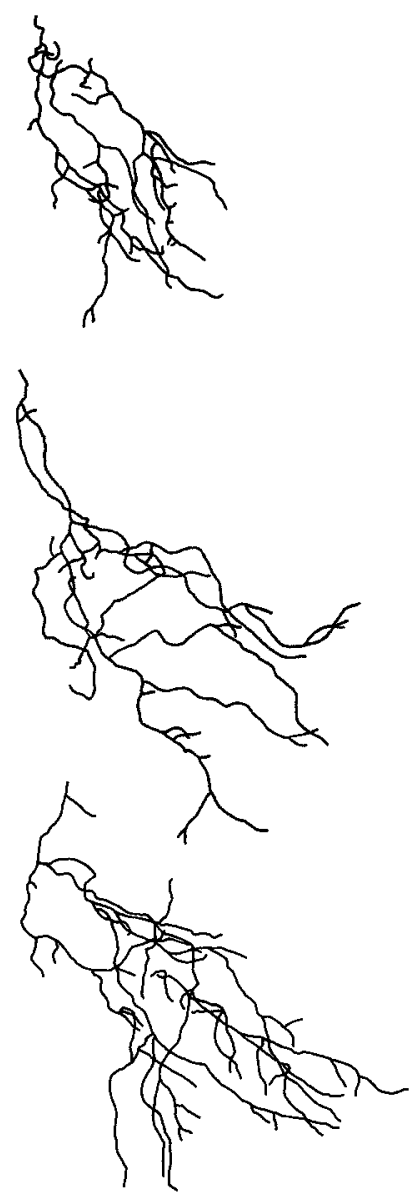

Figure 7. AIP expression in postsynaptic tectal cells modifies presynaptic retinal axon growth. AIP expression in postsynaptic tectal cells increases presynaptic retinal axon growth. Protocol for viral infection, DiI labeling, and in vivo imaging of retinal axon arbors $(A)$. DiI was injected into the retina of stage 46 tadpoles. The next day (day 0), confocal images were taken of individual DiI-labeled retinotectal axons. After imaging, the animals were left untreated or were immediately infected with recombinant vaccinia virus expressing CaMKII-specific inhibitors. Examples of reconstructed single control retinal axons $(B)$ and AIP retinal axons $(C)$ imaged over $3 \mathrm{~d}$. Day 0, Left columns; day 2, right columns. Retinal axon arbors of increasing complexity are displayed from top to bottom. The growth rates of these axons were close to the means of their treatment groups.

\section{DISCUSSION}

The development of functional neural circuits requires that neurons elaborate dendritic and axonal arbors of restricted size. Expansion of arbors into territories of neighboring neurons degrades information transfer, as exemplified in the case of visual projections of TTX-treated kittens (Stryker and Harris, 1986; Shatz and Stryker, 1988; Sretavan et al., 1988) and frog tadpoles (Reh and Constantine-Paton, 1985). Neural activity, at least partially mediated by postsynaptic NMDA receptors, plays a major role in the refinement of neural circuits processing sensory information (Constantine-Paton et al., 1990; Cline, 1991). More recent evidence suggests that activity-dependent mechanisms can operate as stop-growing signals (Baird et al., 1996). Activity can lead to $\mathrm{Ca}^{2+}$ influx through the NMDA receptors, which in turn could activate CaMKII (Fukunaga et al., 1993; Scheetz et al., 1996; Ouyang et al., 1997). 
A

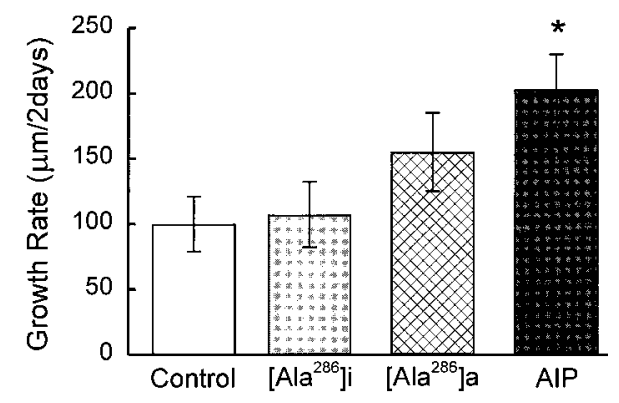

B

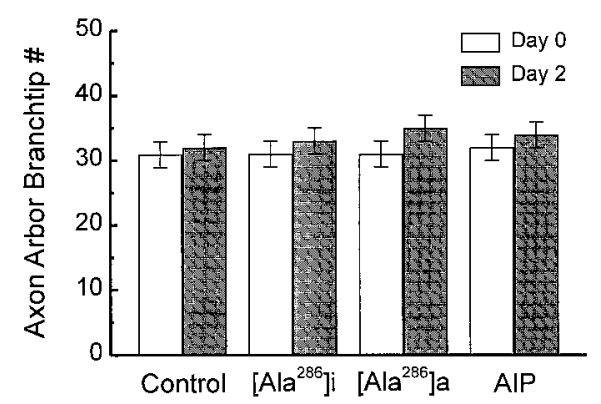

Figure 8. AIP expression in the postsynaptic tectal cells increases the growth of presynaptic retinal axon arbors. Expression of CaMKII inhibitors AIP and $\mathrm{Ala}^{286} \mathrm{a}$ increases the growth rate of branch length $(A)$ but does not change the average branch tip number $(B)$ in the retinal axons. (Control axons, $n=23$; Ala ${ }^{286} \mathrm{i}$ axons, $n=27$; Ala ${ }^{286} \mathrm{i}$ axons, $n=22$; AIP axons, $n=22$ ).

Our goal in these experiments was to test whether endogenous postsynaptic CaMKII activity is required to restrict the elaboration of presynaptic and postsynaptic neuronal processes during neuronal maturation. We demonstrated that viral expression of the CaMKII inhibitor AIP in Xenopus optic tectal cells maintained mature neurons in a rapid growth phase characteristic of immature, CaMKII-deficient neurons. The growth of immature tectal neurons is unaffected by AIP expression, most likely because of their low levels of CaMKII expression. AIP expression in tectal neurons also increased the growth rate of presynaptic retinotectal axon arbors. These data provide strong evidence that CaMKII activity is required to regulate dendritic arbor growth rate in vivo. Based on these observations, we propose that the growth of presynaptic and postsynaptic neuronal structures are coordinated through an activity-dependent mechanism driven by the postsynaptic neuron.

In a complementary set of experiments in which constitutively active CaMKII was expressed in the tectum, elevated postsynaptic CaMKII activity increased the strength of retinotectal synaptic transmission (Wu et al., 1996) and stabilized both postsynaptic tectal cell dendrites (Wu and Cline, 1998) and presynaptic retinal axon arbors (Zou and Cline, 1996a) (Fig. 9A). The rostrocaudal gradient of increasing synaptic strength in retinotectal synaptic transmission correlates with the gradient of increasing stability of dendritic arbors and with increasing expression of endogenous CaMKII in tectal cells (Wu et al., 1996, 1999).

Immunohistochemical detection of myc-tagged AIP indicated that $\sim 30-70 \%$ of tectal cells were infected in the tectal region in which cells were labeled with DiI in these experiments. This infection rate was comparable with that reported previously ( $\mathrm{Wu}$ et al., 1995; Zou and Cline, 1996b). However, because DiI labeling does not persist through the immunocytochemical procedure necessary to visualize the myc-tagged AIP, we could not verify that imaged tectal neurons were infected. Nevertheless, the statistically significant differences in the groups of tectal neurons imaged from AIP virus-infected versus control animals indicate that CaMKII inhibitor AIP expression in tectal neurons altered their dendritic growth.

The data support a model in which postsynaptic CaMKII activity regulates both synaptic strength and neuronal structural dynamics in the developing frog retinotectal projection (Fig. 9B). Correlated retinal inputs activate $\mathrm{NMDA}$ receptors in the postsynaptic tectal cells. The $\mathrm{Ca}^{2+}$ influx through NMDA receptors results in the local activation of CaMKII. Locally elevated CaMKII activity enhances synaptic connections and leads to the stabilization of these synapses and the neuronal structures supporting these synapses. Both postsynaptic tectal cell dendritic and presynaptic retinal axonal branches are stabilized locally and have less dynamic elaboration. In contrast, uncorrelated retinal inputs do not activate NMDA receptors. CaMKII activity is not activated at these synapses, and they are not strengthened. Local presynaptic and postsynaptic structures (i.e., retinal axon and tectal cell dendrites) continue to elaborate and search for more suitable partners to form strong stable synapses.

Our results suggest that endogenous CaMKII activity controls the growth of tectal cell arbors by regulating the dynamic rearrangements of neuronal processes. Cytoskeletal proteins, such as microtubule-associated protein-2, tau, and neurofilaments, can be phosphorylated by CaMKII (Braun and Schulman, 1995). Thus, CaMKII may directly regulate cytoskeletal dynamics in neurons by changing the stability of these proteins. It is also possible that CaMKII activity modulates intermediate events that could ultimately regulate the stability of the neuronal cytoskeleton (Chen et al., 1998).

CaMKII inhibitor AIP expression in postsynaptic tectal cells increased the total branch length of presynaptic retinal axon arbors. Our previous work shows that elevated CaMKII activity in the postsynaptic tectal cells increases the rate of branch retractions without altering rates of branch additions (Zou and Cline, 1996a). Thus, it appears that postsynaptic CaMKII activity levels regulate the elaboration of presynaptic retinal arbors by determining the fate of existing axonal branches; low levels of CaMKII activity promote the extension of branches, whereas higher levels of CaMKII activity increase the rate of branch retractions.

In addition to our observations in the developing frog retinotectal projection, several experiments in other sensory systems also demonstrate that the activity of postsynaptic cells regulates the growth of presynaptic axons (Hahm et al., 1991; Simon et al., 1992; Schlaggar et al., 1993; Hata et al., 1999). Postsynaptic cells may affect presynaptic axons by regulating cell adhesion molecules at synaptic sites (Hall and Sanes, 1993; Fannon and Colman, 1996; Davis et al., 1997) or through retrograde messengers (Wu et al., 1994; Fitzsimonds and Poo, 1998), which act on the presynaptic axons (Renteria and Constantine-Paton, 1995).

AIP expression also promotes the elaboration of local axon arbors in tectal cells. Local axon growth may be regulated by the cell-cell interactions with their postsynaptic partners, similar to the postulated mechanism by which postsynaptic tectal cell CaMKII activity regulates the growth of presynaptic retinotectal axon arbors. Alternatively, decreasing CaMKII activity in tectal 


\section{A Summary of Results}
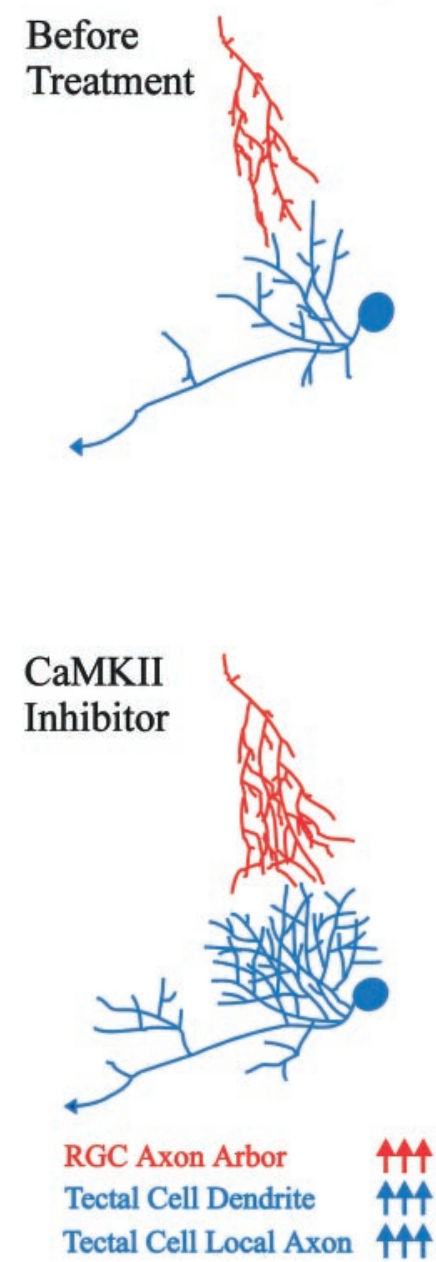
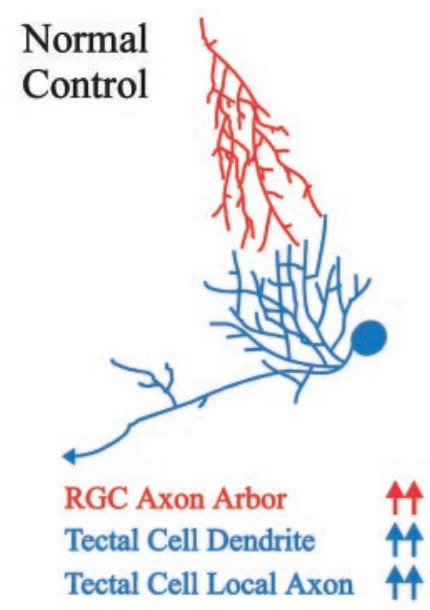

B Proposed Model

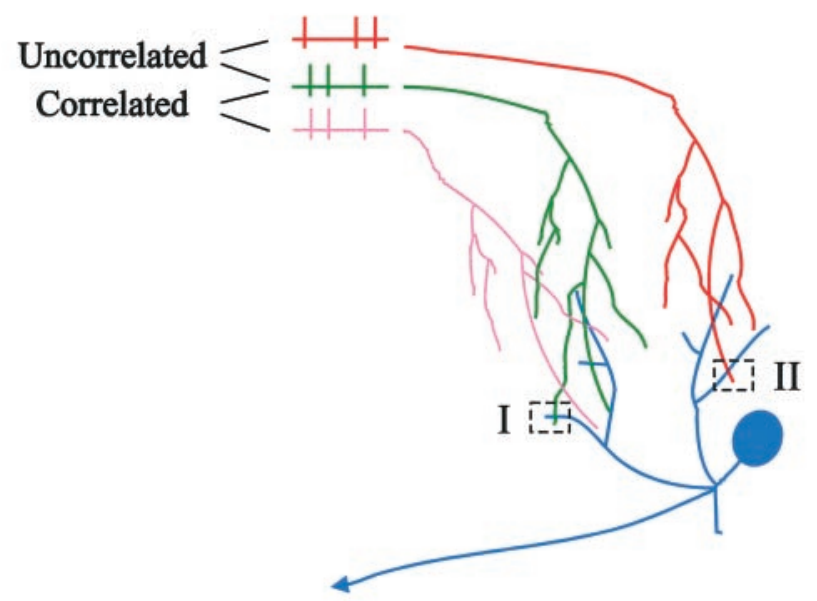

I. Correlated Activity

II. Uncorrelated Activity

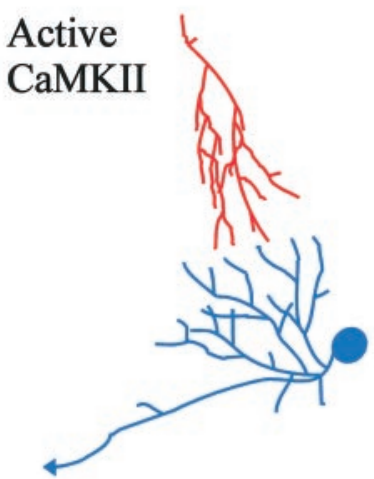

RGC Axon Arbor
Tectal Cell Dendrite

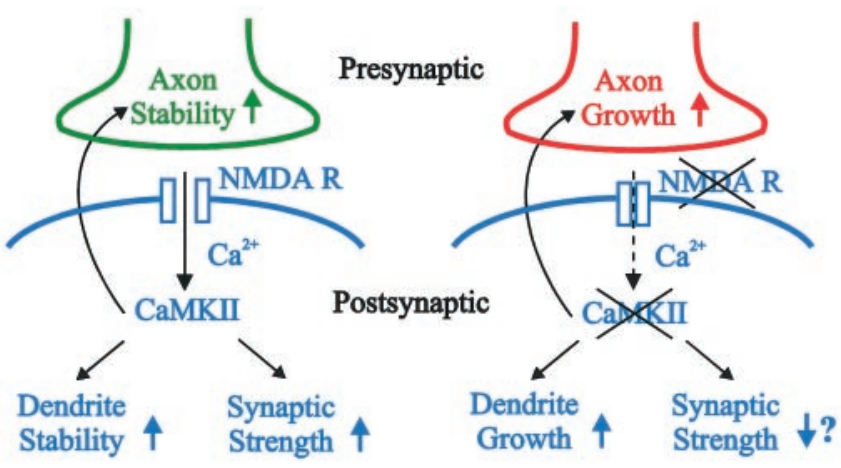

Figure 9. Summary of results and proposed model of how CaMKII activity restricts neuronal elaboration. $A$, CaMKII activity in postsynaptic tectal cells coordinately regulates the growth of presynaptic and postsynaptic neuronal structures. In vivo imaging reveals that the elaboration of postsynaptic tectal cells (blue) and presynaptic RGC axon arbors (red) is increased by the expression of CaMKII inhibitors and stabilized by the expression of constitutively active CaMKII in the tectal cells. $B$, Proposed model of postsynaptic CaMKII activity regulating neuronal structures and synaptic strength. During normal development, correlated presynaptic retinal inputs (green and pink, box I) activate postsynaptic NMDA receptors (NMDA R) on tectal cell dendrites (blue). The resultant $\mathrm{Ca}^{2+}$ influx activates $\mathrm{CaMKII}$ in tectal cells. High levels of CaMKII activity stabilize both presynaptic and postsynaptic neuronal structures and enhance synaptic transmission between the retinal axon and the tectal cell dendrite. Uncorrelated retinal inputs (red and green, box II) do not activate NMDA receptors or CaMKII. In the absence of CaMKII activity, synaptic strength is low, and both presynaptic and postsynaptic neuronal structures continue to elaborate.

cells may increase the growth of all neuronal processes; however, we did not observe the correlated increase between dendritic and axonal arbors predicted by this hypothesis.

\section{REFERENCES}

Baird DH, Trenkner E, Mason CA (1996) Arrest of afferent axon extension by target neurons in vitro is regulated by the NMDA receptor. J Neurosci 16:2642-2648.

Benson D, Isaacson P, Hendry S, Jones E (1991) Differential gene expression for glutamic acid decarboxylase and type II calciumcalmodulin-dependent protein kinase in basal ganglia, thalamus, and hypothalamus of the monkey. J Neurosci 11:1540-1564.

Braun AP, Schulman H (1995) The multifunctional calcium/ calmodulin-dependent protein kinase: from form to function. Annu Rev Physiol 57:417-445.

Chen HJ, Rojas-Soto M, Oguni A, Kennedy MB (1998) A synaptic Ras-GTPase activating protein (p135 SynGAP) inhibited by CaM kinase II. Neuron 20:895-904.
Cline HT (1991) Activity-dependent plasticity in the visual systems of frogs and fish. Trends Neurosci 14:104-111.

Colbran RJ, Fong YL, Schworer CM, Soderling TR (1988) Regulatory interactions of the calmodulin-binding, inhibitory, and autophosphorylation domains of $\mathrm{Ca} 2+/$ calmodulin-dependent protein kinase II. J Biol Chem 263:18145-18151.

Constantine-Paton M, Cline HT, Debski EA (1990) Patterned activity, synaptic convergence and the NMDA receptor in developing visual pathways. Annu Rev Neurosci 13:129-154.

Davis GW, Schuster CM, Goodman CS (1997) Genetic analysis of the mechanisms controlling target selection: target-derived Fasciclin II regulates the pattern of synapse formation. Neuron 19:561-573.

Evan GI, Lewis GK, Ramsay G, Bishop JM (1985) Isolation of monoclonal antibodies specific for human c-myc proto-oncogene product. Mol Cell Biol 5:3610-3616.

Fannon AM, Colman DR (1996) A model for central synaptic junctional complex formation based on the differential adhesive specificities of the cadherins. Neuron 17:423-434. 
Fitzsimonds RM, Poo MM (1998) Retrograde signaling in the development and modification of synapses. Physiol Rev 78:143-170.

Fukunaga K, Stoppini L, Miyamoto E, Muller D (1993) Long-term potentiation is associated with an increased activity of $\mathrm{Ca}^{2+} /$ calmodulin-dependent protein kinase II. J Biol Chem 268:7863-7867.

Hahm J-O, Langdon RB, Sur M (1991) Disruption of retinogeniculate afferent segregation by antagonists to NMDA receptors. Nature 351:568-570.

Hall ZW, Sanes JR (1993) Synaptic structure and development: the neuromuscular junction. Cell 72S:99-102.

Hata Y, Tsumoto T, Stryker MP (1999) Selective pruning of more active afferents when cat visual cortex is pharmacologically inhibited. Neuron 22:375-381.

Ishida A, Kameshita I, Okuno S, Kitani T, Fujisawa H (1995) A novel highly specific and potent inhibitor of calmodulin-dependent protein kinase II. Biochem Biophys Res Commun 212:806-812.

Kelly PT, Weinberger RP, Waxham MN (1988) Active site-directed inhibition of $\mathrm{Ca}^{2+} /$ calmodulin-dependent protein kinase type II by a bifunctional calmodulin-binding peptide. Proc Natl Acad Sci USA 85:4991-4995.

Lisman J (1994) The CaM kinase II hypothesis for the storage of synaptic memory. Trends Neurosci 17:406-412.

Liu X-B, Jones EG (1996) Localization of alpha type II calcium calmodulin-dependent protein kinase at glutamatergic but not $\gamma$-aminobutyric acid (GABAergic) synapses in thalamus and cerebral cortex. Proc Natl Acad Sci USA 93:7332-7336.

Mackett M, Smith GL, Moss B (1985) DNA cloning: a practical approach. Oxford: IRL.

Mainen ZF, Sejnowski TJ (1996) Influence of dendritic structure on firing pattern in model neocortical neurons. Nature 382:363-366.

Malinow R, Schulman H, Tsien RW (1989) Inhibition of postsynaptic PKC or CaMKII blocks induction but not expression of LTP. Science 245:862-866.

Miller SG, Kennedy MB (1986) Regulation of brain type II $\mathrm{Ca}^{2+} /$ calmodulin-dependent protein kinase by autophosphorylation: a $\mathrm{Ca}^{2+}$. triggered molecular switch. Cell 44:861-870.

Nieuwkoop PD, Faber J (1956) Normal table of Xenopus laevis (Daudin). Amsterdam: Elsevier-North Holland.

O'Rourke NA, Fraser SE (1990) Dynamic changes in optic fiber terminal arbors lead to retinotopic map formations: an in vivo confocal microscopic study. Neuron 5:159-171.

Ouyang Y, Kantor D, Harris KM, Schuman EM, Kennedy MB (1997) Visualization of the distribution of autophosphorylated calcium/ calmodulin-dependent protein kinase II after tetanic stimulation in the CA1 area of the hippocampus. J Neurosci 17:5416-5427.

Payne ME, Fong YL, Ono T, Colbran RJ, Kemp BE, Soderling TR, Means AR (1988) Calcium/calmodulin-dependent protein kinase II. Characterization of distinct calmodulin binding and inhibitory domains. J Biol Chem 263:7190-7195.

Peters A, Jones EG (1984) Cerebral cortex, Vol 1, Cellular components of the cerebral cortex. New York: Plenum.

Reh T, Constantine-Paton M (1985) Eye-specific segregation requires neural activity in three-eyed Rana pipiens. J Neurosci 5:1132-1143.

Reilen AR, Tint IS, Peunova NI, Enikolopov GN, Gelfand VI (1998) Regulation of organelle movement in melanophores by protein kinase A (PKA), protein kinase C (PKC), and protein phosphatase 2A (PP2A). J Cell Biol 142:803-813.
Renteria RC, Constantine-Paton M (1995) Exogenous nitric oxide causes collapse of retinal ganglion cell axonal growth cones in vitro. J Neurobiol 29:415-428.

Scheetz AJ, Prusky GT, Constantine-Paton M (1996) Chronic NMDA receptor antagonism during retinotopic map formation depresses $\mathrm{CaM}$ kinase II differentiation in rat superior colliculus. Eur J Neurosci 8:1322-1328.

Schlaggar BL, Fox K, O’Leary DD (1993) Postsynaptic control of plasticity in developing somatosensory cortex. Nature 364:623-626.

Schworer CM, Colbran RJ, Keefer JR, Soderling TR (1988) $\mathrm{Ca}^{2+} /$ calmodulin-dependent protein kinase II. Identification of a regulatory autophosphorylation site adjacent to the inhibitory and calmodulinbinding domains. J Biol Chem 263:13486-13489.

Shatz CJ, Stryker MP (1988) Prenatal tetrodotoxin infusion blocks segregation of retinogeniculate afferents. Science 242:87-89.

Sik A, Hajos N, Gulacsi A, Mody I, Freund TF (1998) The absence of a major $\mathrm{Ca}^{2+}$ signaling pathway in GABAergic neurons of the hippocampus. Proc Natl Acad Sci USA 95:3245-3250.

Simon DK, Prusky GT, O'Leary DDM, Constantine-Paton M (1992) $N$-methyl-D-aspartate receptor antagonists disrupt the formation of a mammalian neural map. Proc Natl Acad Sci USA 89:10593-10597.

Smith MK, Colbran RJ, Brickey DA, Soderling TR (1992) Functional determinants in the autoinhibitory domain of calcium/calmodulindependent protein kinase II. Role of His 282 and multiple basic residues. J Biol Chem 267:1761-1768.

Sretavan DW, Shatz CJ, Stryker MP (1988) Modification of retinal ganglion cell axon morphology by prenatal infusion of tetrodotoxin. Nature 336:468-471.

Stryker MP, Harris WA (1986) Binocular impulse blockade prevents the formation of ocular dominance columns in cat visual cortex. J Neurosci 6:2117-2133.

Waldmann R, Hanson PI, Schulman H (1990) Multifunctional $\mathrm{Ca}^{2+}$ / calmodulin-dependent protein kinase made $\mathrm{Ca}^{2+}$ independent for functional studies. Biochemistry 29:1679-1684.

Wang J, Renger JJ, Griffith LC, Greenspan RJ, Wu CF (1994) Concommitant alterations of physiological and developmental plasticity in Drosophila CaM kinase II-inhibited synapses. Neuron 13:1373-1384.

Wu G, Malinow R, Cline HT (1996) Maturation of a central glutamatergic synapse. Science 274:972-976.

Wu G-Y, Cline HT (1998) Stabilization of dendritic arbor structure in vivo by CaMKII. Science 279:222-226.

Wu G-Y, Zou D-J, Koothan T, Cline HT (1995) Infection of frog neurons with vaccinia virus permits in vivo expression of foreign proteins. Neuron 14:681-684.

Wu G-Y, Zou D-J, Rajan I, Cline HT (1999) Dendritic dynamics in vivo change during neuronal maturation. J Neurosci 19:4472-4483.

Wu HH, Williams CV, McLoon SC (1994) Involvement of nitric oxide in the elimination of a transient retinotectal projection in development. Science 265:1593-1596.

Zou D-J, Cline HT (1996a) Expression of constitutively active CaMKII in target tissue modifies presynaptic axon arbor growth. Neuron $16: 529-539$.

Zou D-J, Cline HT (1996b) Control of retinotectal axon arbor growth by postsynaptic CaMKII. In: Progress in brain research. Neuronal development and plasticity (Mize RR, Erzurumlu RS, eds). Amsterdam: Elsevier Science. 